\title{
KINETICS OF THE CERCARIA-SCHISTOSOMULUM TRANSFORMATION IN VIVO: 2. THE EFFECT OF OXAMNIQUINE
}

\author{
A. L. Melo' 1 and L.H. Pereira1
}

\begin{abstract}
To study the cercaria-schistosomulum transformation in vivo, under the influence of an antischistosomal compound (oxamniquine), a model using cercarial injections into the abdominal cavity of mice was chosen. This procedure provided easy and reproducible recoveries of larvae from peritoneal washings with appropriate solutions for a long time (30 to $180 \mathrm{~min}$ ) after inoculation. The results show that high doses of oxamniquine (given intramuscularly one hour before the infection) produce a marked delay in the kinetics of the cercaria-schistosomulum transformation. Cercariae, tail-less cercarial bodies and schistosomula were recovered from the peritoneal cavity of drug treated mice in numbers significantly different from those recovered from untreated mice.

Key words: Schistosoma mansoni. Cercariae. Schistosomule. In vivo transformation. Oxamniquine.
\end{abstract}

In the chemotherapy of schistosomiasis, oxamniquine has been used for about 10 years by oral administration.

The compound is active intramuscularly at $200 \mathrm{mg} / \mathrm{kg}$ against mature schistosomes and young larvae in laboratory mice 8 .

Different routes of experimental infection do not alter the results, and activity against early developing forms of the parasite has been confirmed after exposure of mouse skin to Schistosoma mansoni cercariae ${ }^{5}$, and after inoculation into the peritoneal cavity of mice 237891011 . Using doses of 60 to $400 \mathrm{mg} / \mathrm{kg}$, on the transformation of cercariae into schistosomula, no action was found by Pellegrino et $\mathrm{al}^{8}$. Melo et $\mathrm{al}^{2}$ showed that doses of 1,000 and $2,000 \mathrm{mg} / \mathrm{kg}$ of the drug produced some delay in the transformation process, 3 hours after cercarial inoculation. Doses of $4,000 \mathrm{mg} / \mathrm{kg}$ of oxamniquine can also inhibit the loss of the tail of cercaria ${ }^{3}$.

The transformation of cercaria (a larva adapted to a freshwater environment) to schistosomulum (an organism newly adapted to host conditions) involves several steps: observations on that transformations. following the intraperitoneal inoculation of cercariae ${ }^{4}$ provided some answers to the question. The possibility to discriminate such steps in vivo, using antischistosomal drugs, is attractive.

The purpose of the present work is to verify the activity of oxamniquine, at different doses and different times, on the transformation process of cercariae into schistosomula.

1. Departamento de Parasitologia e Grupo Interdepartamental de Estudos sobre Esquistossomose (GIDE), ICB, Universidade Federal de Minas Gerais. Caixa Postal 2486, 30000 Belo Horizonte, Brasil.

This work received financial support from FINEP, $\mathrm{CNPq}$ Brazil, and from the Parasitic Diseases Programme, WHO-Switzerland.

Recebido para publicą̧ão em 18/3/85

\section{MATERIAL AND METHODS}

The method described by Pereira et al ${ }^{10}$ to study the chemoprophylactic action of compounds on schistosomula recovered from the peritoneal cavity of mice was used in all experiments. Albino mice (male, weighing about $20 \mathrm{~g}$ ) were inoculated intraperitoneally with Schistosoma mansoni cercariae(L. E. strain), shed by laboratory-reared and infected Biomphalaria glabrata (Belo Horizonte strain). The organisms were concentrated by the method of Pellegrino \& Macedo ${ }^{6}$, and $0.5 \mathrm{ml}$ of well water, containing about 500 larvae, were injected by a Cornwall syringe with a $20 \times 10$ gauge needle.

Appropriate doses of oxamniquine were mixed with polyethylene glycol in a mortar and injected $(0.1 \mathrm{ml})$ intramuscularly in the hind leg. The drug was administered one hour before the cercarial injections and doses of $500,1,000,2,000$ or $4,000 \mathrm{mg} / \mathrm{kg}$ were given to four groups of five animals each. Untreated animals served as controls.

At different time intervals ranging from 30 minutes to 3 hours after inoculation the mice were killed by cervical fracture, and the parasites recovered from the peritoneal cavity with saline. They were then concentrated by centrifugation and counted under a dissecting microscope ${ }^{10}$.

The larvae were classified initially as cercariae and tailess organisms. To separate cercarial bodies (which remain alive in fresh water) from schistosomula (which die in such conditions), $5 \mathrm{ml}$ of distilled water was dropped into a Petri dish containing the organisms. After $10 \mathrm{~min}$, the live and dead larvae were recounted. In addition to the absence of motility, dead larvae showed herniation of acetabulum. Two vital stains (neutral red and alizarin) were added to the suspension of organisms to characterize the acetabular glands.

\section{RESULTS}

Data are summarized in Figures 1 and 2. About $30 \%$ of the inoculated cercarie were recovered from the peritoneal cavity of all mice. Marked differences 
Melo AL, Pereira LH. Kinetics of the cercaria-schistosomulum transformation in vivo: 2. The effect of oxamniquine. Revista da Sociedade Brasileira de Medicina Tropical 18: 251-255, Out-Dez, 1985

DEAD TAILLESS
ORGANISMS

SCHISTOSOMULA $\square$ LIVING CERCARIAL
BODIES

LIVING CERCARIAE
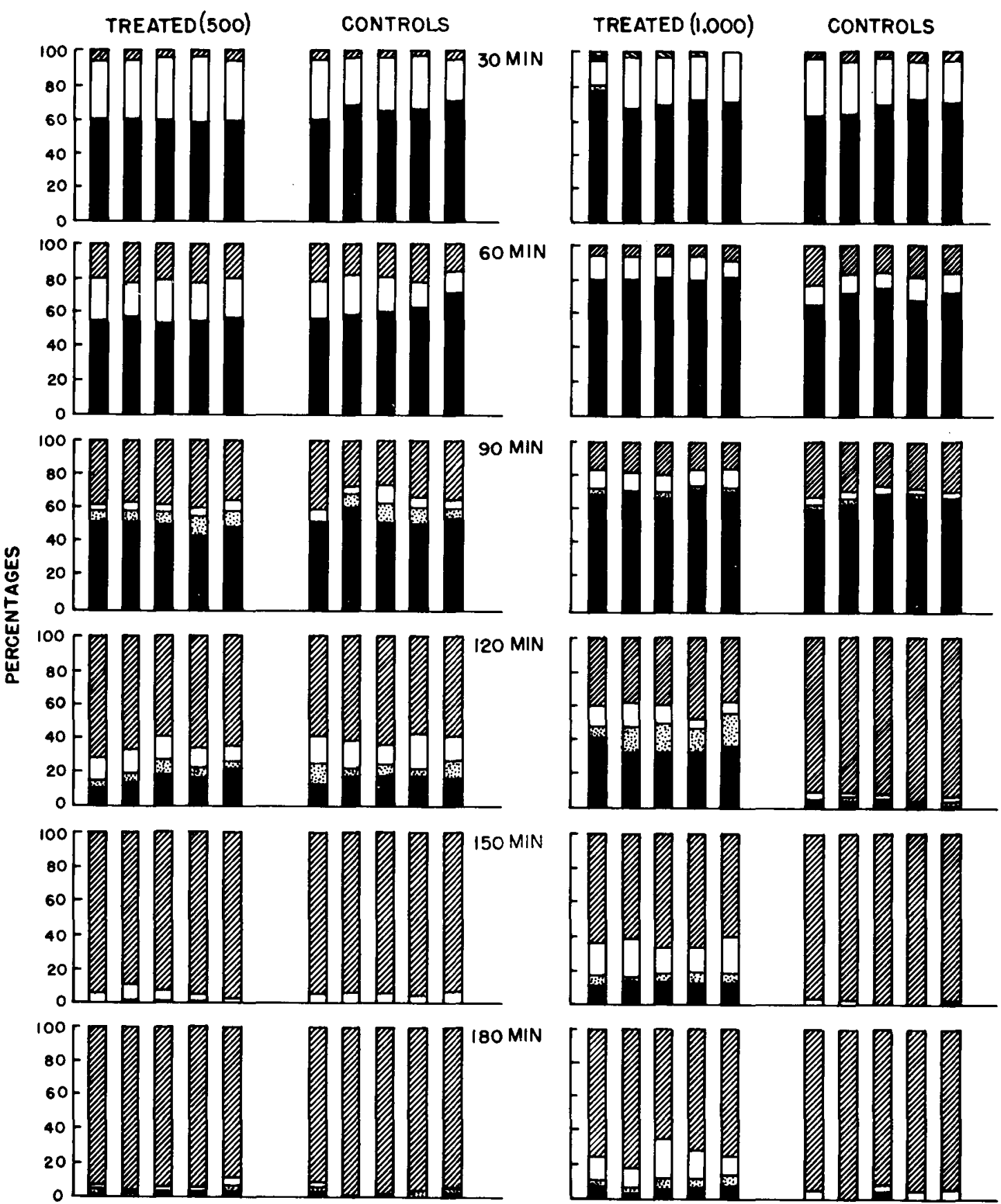

Figure 1 -Percent distribution of larvae recovered from the peritoneal cavity of mice treated with 500 and $1,000 \mathrm{mg} / \mathrm{kg}$ oxamniquine, 1 hour before infection. 
Melo AL, Pereira LH. Kinetics of the cercaria-schistosomulum transformation in vivo: 2 . The effect of oxamniquine. Revista da Sociedade Brasileira de Medicina Tropical 18: 251-255, Out-Dez, 1985
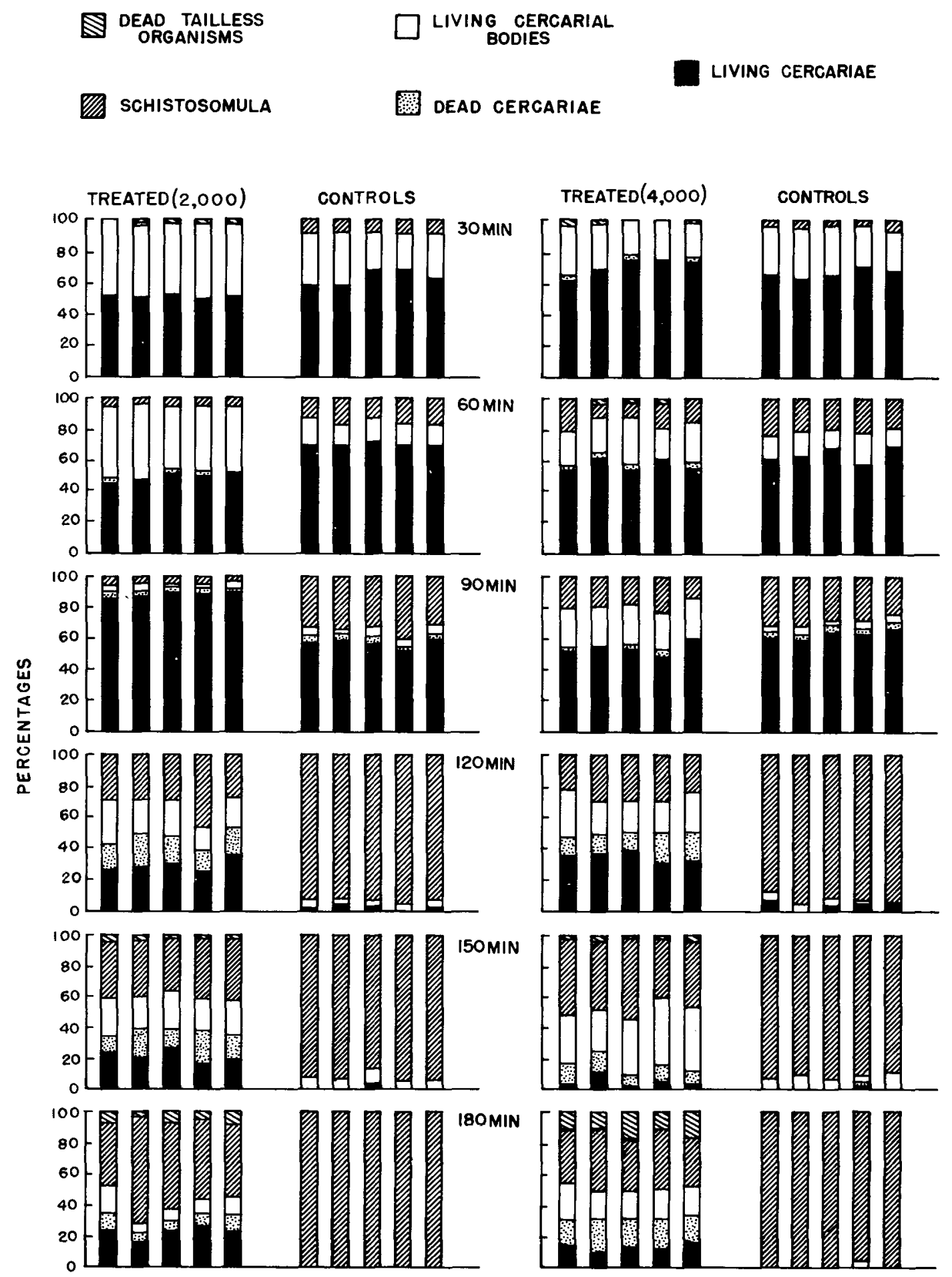

Figure 2 - Percent distribution of larvae recovered from the peritoneal cavity of mice treated with 2,000 and $4,000 \mathrm{mg} / \mathrm{kg}$ oxamniquine, 1 hour before infection. 
Melo AL, Pereira LH. Kinetics of the cercaria-schistosomulum transformation in vivo: 2 . The effect of oxamniquine. Revista da Sociedade Brasileira de Medicina Tropical 18: 251-255, Out-Dez, 1985

were observed between larvae recovered from the control mice and the animals treated with oxamniquine at $1,000,2,000$ or $4,000 \mathrm{mg} / \mathrm{kg}$.

Percentages of living cercariae from larvae recovered from treated and control mice were appropriated changed to $\operatorname{arc} \sin \sqrt{ } \mathbf{x}$, and the Student's t test was performed.

As can be seen in Figure 1, the behaviour of experimental groups (receiving the drug at $500 \mathrm{mg} / \mathrm{kg}$ ) did not differ from the control group during the observed time (30 to 180 minutes after cercarial inoculation). With $1,000 \mathrm{mg} / \mathrm{kg}$, differences were observed between the treated animals and controls after $60 \mathrm{~min} .(\mathrm{p}<0.01)$ and $90(\mathrm{p}<0.05)$. After this time, the groups showed marked differences in all observations.

An evident delay in the transformation process, was found at different times of observation, using $2,000 \mathrm{mg} / \mathrm{kg}$ of oxamniquine (Fig. 2).

Using the dose of $4,000 \mathrm{mg} / \mathrm{kg}$ of oxamniquine (Fig. 2), showed differences in all times, but abnormal larvae were found: organisms presenting characteristics of both cercaria and schistosomulum, suggesting inhibition of cercarial decaudation.

The use of the vital stain to observe the effects of oxamniquine on the acetabular glands did not show marked differences. When alizarin or neutral red were used almost all schistosomula incorporated the vital stain, the colour being generally intense (as in the cercariae), in both groups.

\section{DISCUSSION}

The study of cercaria-schistosomulum transformation in the peritoneal cavity of albino mice, under the effects of oxamniquine, was first carried out by Melo et $\mathrm{al}^{2}$. High doses produced delay of cercariaschistosomulum transformation following intraperitoneal injections of cercarie into mice. Cercariae, tailless cercarial bodies and schistosomula were recovered ( 3 hours after the cercarial inoculations) from the peritoneal cavity of drug treated animals, in numbers significantly different from those recovered from untreated mice. Since untreated mice induced transformation of almost all the injected cercariae, the data suggested that the compound is active during the process of host-larvae adaptation. As changes usually start with the detachment of the tail followed by loss, rupture or changes of the glycocalix in untreated mice (Melo, 1985, unpublished data), the steps could be inhibited by high doses of oxamniquine.

In this work we used again the inoculation of cercariae into the peritoneal cavity of mice, to follow in detail the steps involved in the progressive adaptation of cercariae to the vertebrate host under the effects of oxamniquine. Most cercariae reach the schistosomular stage between 90-120 minutes after intraperitoneal inoculation in the control groups and in the mice treated with $500 \mathrm{mg} / \mathrm{kg}$ of oxamniquine. At doses of $1,000,2.000$ or $4,000 \mathrm{mg} / \mathrm{kg}$ changes in the transformation process can be seen.
Melo \& Pereira ${ }^{3}$ showed that $4,000 \mathrm{mg} / \mathrm{kg}$, oxamniquine inhibited cercariae decaudation, but the progressive loss of glycocalix was not inhibited by this compound.

In the present study, the data suggest that the oxamniquine used at $1,000,2,000$ and $4,000 \mathrm{mg} / \mathrm{kg}$ produces a delay in the tranformation process. High numbers of larvae recovered from treated mice have not lost their tail, and did not show water intolerance, indicating a partial or total inhibition in the loss of glycocalix.

On the other hand, it was observed that the dose of $4,000 \mathrm{mg} / \mathrm{kg}$ inhibited the loss of the tail significantly $(p<0.01)$. However, the other changes of the cercaria to the schistosomular stage were observed (loss of glycocalix, water intolerance, worm-like movements), suggesting that these changes may start without the tail detachment.

Some authors 112 believe that the loss of the cercarial tail is a mere consequence of muscular activity of the organisms. If oxamniquine affects the cercariae by reducing their movements, the detachment of the tail would be less likely to occur.

The delay in the transformation process, under an antischistosomal compound, could be explained by an inhibitory mechanism of tail loss or by alterations in the capability of loss, rupture or changes in the glycocalix.

\section{$R E S U M O$}

Para estudar a transformação da cercária em esquistossômulo in vivo, sob a influência de um composto ativo contra o Schistosoma mansoni, foi escolhida a técnica da inoculação de cercárias na cavidade peritoneal de camundongos. Este procedimento se mostrou reproduzivel e promoveu uma rápida e fácil recuperacão das larvas após a lavagem das vísceras abdominais com solução apropriada. $O$ s resultados obtidos sugerem que altas doses de oxamniquine (via intramuscular), uma hora antes da infecção, produzem um evidente atraso na cinética do processo de transformação da cercária em esquistossômulo. Cercárias, corpos cercarianos e esquistossômulos foram recuperados da cavidade peritoneal de camundongos tratados em números diferentes daqueles recuperados dos animais controles.

Palavras chaves: Schistosoma mansoni Cercária. Esquistossômulo. Transformação in vivo. Oxamniquine.

\section{REFERENCES}

1. Howells RE, Ramalho-Pinto FJ, Gazzinelli G, Oliveira CC, Figueiredo EA, Pellegrino J. Schistosoma mansoni: the mechanism of cercarial tail loss and its significance to host penetration. Experimental Parasitology 36: 373-375, 1974.

2. Melo AL, Pereira LH, Correa MCR. In vivo cercariaschistosomulum transformation: inhibitory effect of oxamniquine. Transactions of the Royal Society of Tropical Medicine and Hygiene 72: 158-159, 1978. 
3. Melo AL, Pereira LH. Inhibitory effect of oxamniquine on the detachment of the tail of Schistosoma mansoni. The Journal of Parasitology 66: 1067-1068, 1980.

4. Melo AL, Pereira LH. Kinetics of the cercaria-schistosomulum transformation in vivo. Revista da Sociedade Brasileira de Medicina Tropical 18: 17-21, 1985.

5. Oliveira MA, Pellegrino J, Pereira LH, Valadares TE. Migration and fate of $S$. mansoni in mice treated with oxamniquine. Revista do Instituto de Medicina Tropical de São Paulo 18: 298-300, 1976.

6. Pellegrino J, Macedo, DG. A simplified method for the concentration of cercarie. The Journal of Parasitology 41: 329-330, 1955.

7. Pellegrino J, Pereira LH, Mello RT, Katz N. Activity of some tetrahydro-and pyrazinoquinolines against early developing forms of $S$. mansoni. The Journal of Parasitology 60: 723-725, 1974.

8. Pellegrino J, Pereira LH, Mello RT. Preliminary laboratory trials of oxamniquine as a prophylactic agent in schistosomiasis. Revista do Instituto de Medicina Tropical de São Paulo 18: 97-101, 1976.

9. Pellegrino J, Mello RT, Pereira LH. Further studies on the chemoprophylactic activity of pyrazinoquinolines in experimental schistosomiasis mansoni. Revista do Instituto de Medicina Tropical de São Paulo 18: 149151,1976

10. Pereira LH, Pellegrino J, Valadares TE, Mello RT, Coelho PMZ. A new approach for screening prophylactic agents in schistosomiasis. Revista do Instituto de Medicina Tropical de São Paulo 16: 123-126, 1974.

11. Pereira LH, Pellegrino J, Mello RT. Activity of known schistosomal agents on early developing forms of $S$. mansoni. The Journal of Parasitology 61: 249-252, 1975.

12. Ramalho-Pinto FJ, Gazzinelli G, Howells RE, MotaSantos TA, Figueiredo EA, Pellegrino J. Schistosoma mansoni: a defined system for the step-wise transformation of the cercaria to schistosomule in vitro. Experimental Parasitology 36: 360-372, 1974. 